\title{
Evaluation of the updated regional climate model RACMO2.3: summer snowfall impact on the Greenland Ice Sheet
}

\author{
B. Noël ${ }^{1}$, W. J. van de Berg ${ }^{1}$, E. van Meijgaard ${ }^{2}$, P. Kuipers Munneke ${ }^{1}$, R. S. W. van de Wal ${ }^{1}$, and M. R. van den \\ Broeke $^{1}$ \\ ${ }^{1}$ Institute for Marine and Atmospheric research Utrecht, University of Utrecht, Utrecht, the Netherlands \\ ${ }^{2}$ Royal Netherlands Meteorological Institute, De Bilt, the Netherlands \\ Correspondence to: B. Noël (b.p.y.noel@uu.nl)
}

Received: 27 January 2015 - Published in The Cryosphere Discuss.: 24 February 2015

Revised: 29 July 2015 - Accepted: 18 August 2015 - Published: 18 September 2015

\begin{abstract}
We discuss Greenland Ice Sheet (GrIS) surface mass balance (SMB) differences between the updated polar version of the RACMO climate model (RACMO2.3) and the previous version (RACMO2.1). Among other revisions, the updated model includes an adjusted rainfall-to-snowfall conversion that produces exclusively snowfall under freezing conditions; this especially favours snowfall in summer. Summer snowfall in the ablation zone of the GrIS has a pronounced effect on melt rates, affecting modelled GrIS SMB in two ways. By covering relatively dark ice with highly reflective fresh snow, these summer snowfalls have the potential to locally reduce melt rates in the ablation zone of the GrIS through the snow-albedo-melt feedback. At larger scales, SMB changes are driven by differences in orographic precipitation following a shift in large-scale circulation, in combination with enhanced moisture to precipitation conversion for warm to moderately cold conditions. A detailed comparison of model output with observations from automatic weather stations, ice cores and ablation stakes shows that the model update generally improves the simulated SMBelevation gradient as well as the representation of the surface energy balance, although significant biases remain.
\end{abstract}

\section{Introduction}

Since the mid-1990s, atmospheric and oceanic warming in the Arctic has led to accelerated Greenland ice sheet (GrIS) mass loss (Enderlin and Howat, 2013; Fettweis et al., 2013; Wouters et al., 2013). Combined observational and model studies show that increased meltwater runoff, and solid ice discharge through the acceleration of marine-terminating outlet glaciers (Hanna et al., 2009; Nick et al., 2009; Fettweis et al., 2011; Rignot et al., 2011), account for $\sim 60$ and $\sim 40 \%$ respectively of the recent GrIS mass loss (Rignot et al., 2008; Van den Broeke et al., 2009; Enderlin and Howat, 2013).

Since surface melt over the GrIS is mainly driven by the absorption of shortwave radiation (Van den Broeke et al., 2008), surface albedo is a primary factor governing ice sheet surface mass balance (SMB) (Bougamont et al., 2005; Tedesco et al., 2011; Fitzgerald et al., 2012) and surface energy balance (SEB) (Tedesco et al., 2008; Van Angelen et al., 2012). Ice albedo is mainly a function of impurity content, while snow albedo is sensitive to several snow physical properties, e.g., grain size, liquid water content, soot concentration and the presence of cryoconite. Satellite and in situ observations have revealed a general decay of GrIS surface albedo in recent years (Box et al., 2012; Stroeve et al., 2013). In the ablation zone, this decrease is mainly caused by the prolonged exposure of dark, bare ice (Fettweis et al., 2011; Tedesco et al., 2011). In the accumulation zone, it is proposed that higher temperatures lead to enhanced snow metamorphism and surface darkening (Box et al., 2012), resulting in enhanced melt through the positive melt-albedo feedback (Stroeve, 2001).

Summer snowfall events can interrupt this feedback, by covering dark ice and/or metamorphosed snow with a highly reflective fresh snow layer. Greuell and Oerlemans (1986) showed that significant summer snowfall events (> $5 \mathrm{mmWE}$ ) on an Alpine glacier caused a major reduction in ablation during the following days, subsequently 
leading to a long-term positive SMB anomaly. They estimated this positive SMB response to be two to three times larger than the mass of deposited solid precipitation. Fettweis et al. (2005) analysed two heavy snowfall events in south-east Greenland at the end of July 1991, using MAR (Modèle Atmosphérique Régional) and AVHRR satellite imagery. These events temporarily raised surface albedo, delaying the appearance of darker bare ice. Based on data from automatic weather stations (AWS), Van den Broeke et al. (2011) showed that even minor summer snowfall events $(<5 \mathrm{mmWE})$ can considerably reduce surface melting.

Therefore, an accurate representation of (summer) snowfall events is essential to model the SMB of the GrIS (Fettweis et al., 2005; Van Angelen et al., 2012). This requires a high-resolution model to resolve the narrow ablation zone, and an explicit model of atmospheric and surface snow/ice physics. Here, we use the polar version of the regional atmospheric climate model RACMO2.3 at $11 \mathrm{~km}$ horizontal resolution, which is coupled to a multilayer snow model with prognostic albedo formulation. We compare the simulated GrIS SMB and SEB with the previous model version (RACMO2.1, Van Angelen et al., 2012) and with ice cores, stake and AWS measurements along the K-transect in west Greenland, with special reference to the representation of summer snowfalls. In Sect. 2, the physics upgrades in RACMO2.3 and the measurements along the K-transect are briefly described. The impact of upgraded physics on GrIS SMB through the snow-albedo feedback is discussed in Sect. 3. Section 4 evaluates model output using K-transect and accumulation zone data, after which conclusions are drawn in Sect. 5.

\section{Model and data}

\subsection{The regional climate model RACMO2}

The Regional Atmospheric Climate Model (RACMO2) is developed and maintained at the Royal Netherlands Meteorological Institute (KNMI) (Van Meijgaard et al., 2008). RACMO2 adopts the atmospheric physics module from the European Centre for Medium-Range Weather Forecasts Integrated Forecast System (ECMWF-IFS) and the dynamical core of the High Resolution Limited Area Model (HIRLAM) (Undèn et al., 2002). The polar version of RACMO2 was developed by the Institute for Marine and Atmospheric Research (IMAU), Utrecht University, to specifically represent the SMB evolution over the ice sheets of Greenland, Antarctica and other glaciated regions. To that end, the atmosphere model has been interactively coupled to a multilayer snow model that simulates meltwater percolation, refreezing and runoff (Ettema et al., 2010). It includes an albedo scheme with prognostic snow grain size (Kuipers Munneke et al., 2011) and a drifting snow routine that simulates interactions between drifting snow, the ice sheet surface and the lower atmosphere (Lenaerts et al., 2012).

\subsection{RACMO2.3 update}

The RACMO2 physics package has recently been updated from cycle CY23r4 used in RACMO2.1 (White, 2001) to cycle CY33r1 in the current RACMO2.3 version (ECMWFIFS, 2008). These updates include major changes in the description of cloud microphysics, surface and boundary layer turbulence, and radiation transport (Van Wessem et al., 2014). The updated physics package includes an eddydiffusivity mass flux scheme (Siebesma et al., 2007), representing turbulence and shallow convection in the atmospheric boundary layer. The surface flux computation is based on Monin-Obukhov similarity theory (Beljaars et al., 2004). The new radiation scheme McRad (Morcrette et al., 2008), based on the Monte Carlo independent column approximation (Barker et al., 2008), computes the shortwave and longwave radiation transmission through clouds. In addition, the interaction of shortwave or longwave radiation with multilayered clouds has been improved by revising the cloud optical properties (ECMWF-IFS, 2008).

The new cloud scheme includes an ice supersaturation parameterisation, which prolongs the vapour phase at low temperatures (Tompkins et al., 2007). The auto-conversion coefficient, controlling the conversion rate of water-vapour into precipitation in convective clouds, has been defined individually for liquid and ice water clouds, following Sundqvist (1978). Moreover, under marginally freezing conditions, i.e., between -7 and $-1{ }^{\circ} \mathrm{C}$, precipitation occurs exclusively as snowfall even though the precipitating clouds are mixed phase. In the previous model version, similar atmospheric conditions could also have resulted in a mix of liquid and solid precipitation for temperatures above $-7^{\circ} \mathrm{C}$. The update results in improved relative contributions of rainfall and snowfall to the total precipitation flux (Lin et al., 1983). Furthermore, the cloud water-to-snowfall conversion coefficient now remains constant for liquid $\left(>0^{\circ} \mathrm{C}\right)$ and mixed phase clouds $\left(-23\right.$ to $\left.0^{\circ} \mathrm{C}\right)$ whereas it decreases with temperature for ice clouds $\left(<-23^{\circ} \mathrm{C}\right)$, resulting in slower snowfall production. The cloud content to ice and liquid water conversion coefficients have been increased in CY33r1 to reduce the overestimated updraft condensation simulated in previous cycles, leading to enhanced convective precipitations (ECMWF-IFS, 2008; Van Wessem et al., 2014). Other minor adjustments have been applied to the physics package and the dynamical core but these are not relevant for this study. A complete overview of all updates is provided by ECMWFIFS (2008) and Van Meijgaard et al. (2012).

\subsection{RACMO2 simulations set-up}

In the polar version of RACMO2.3, identical domain and resolutions ( $\sim 11 \mathrm{~km}, 40$ vertical layers) were used as in the 
previous RACMO2.1 simulation (Van Angelen et al., 2013). The integration domain includes the GrIS, the Canadian Arctic Archipelago, Iceland and Svalbard. At the lateral atmospheric boundaries, RACMO2.3 is forced at 6-hourly time interval by reanalysis data of ERA-40 (Uppala et al., 2005) for the period 1958-1978 and ERA-Interim (Stark et al., 2007; Dee et al., 2011) for the period 1979-2014. Sea surface temperature and sea ice cover are prescribed from the same reanalysis data. Since RAMCO2.1 has been forced by ERAInterim data only for the period 1990-2012 and by ERA40 prior to that, we compare model results for the overlapping period (1990-2012). This period coincides with longterm SMB and AWS measurements performed along the Ktransect in west Greenland, which are therefore also used for model evaluation (see Sect. 2.4) together with accumulation data from ice cores covering the same period.

In both RACMO2 versions, Moderate Resolution Imaging Spectroradiometer (MODIS) albedo products (Stroeve et al., 2005) are used to prescribe a background ice albedo, which is assumed to vary in space but to be constant in time. The background ice albedo field (Fig. 1) consists of the lowest $5 \%$ albedo values retrieved from 16-day integrated MODIS data (MOD43) at 0.05 degree of spatial resolution for the period 2001-2012 and are clipped between 0.30 and 0.55 (Van Angelen et al., 2012).

\subsection{Observational data}

For model evaluation, we use long-term measurements from the K-transect, operated by the Institute for Marine and Atmospheric Research of Utrecht University in the Netherlands. The K-transect runs for a distance of approximately $140 \mathrm{~km}$ from the ice margin through the ablation zone and into the lower accumulation zone of the west Greenland ice sheet along $\sim 67^{\circ} \mathrm{N}$, covering the elevation interval between 400 and 1850 m a.s.l. (Fig. 1, white dots). Since 1990, annual stake measurements have been performed at eight sites along the transect: S4, S5, SHR, S6, S7, S8, S9 and S10 (Van de Wal et al., 2005, 2012). Since August 2003, three AWS with the capability to close the SEB have been operated at sites S5 $(\sim 500 \mathrm{~m}$ a.s.1.), S6 $(\sim 1000 \mathrm{~m}$ a.s.1. $)$ and $\mathrm{S} 9(\sim 1500 \mathrm{~m}$ a.s.1. $)$ (Van den Broeke et al., 2008, 2009, 2011). Stations S5 and S6 are located in the ablation zone at about 5 and $40 \mathrm{~km}$ from the ice sheet margin, while station $\mathrm{S} 9$ is located close to the equilibrium line at approximately $90 \mathrm{~km}$ from the ice sheet margin. Since 2011, an AWS is also operated in the accumulation zone at $\mathrm{S} 10(\sim 1850 \mathrm{~m})$, about $140 \mathrm{~km}$ from the ice sheet margin. At this location, data consist of a merged time series collected at KAN_U $(\sim 1850 \mathrm{~m})$ in 2010 and S10 for 20112012. Both stations are located $\sim 30 \mathrm{~m}$ apart, carry the same instrumentation with similar setup and present measurements overlap for the period 2011-2012. During the overlapping period, only differences smaller than the measurements uncertainty were observed. Therefore, a combined time series was obtained by substituting KAN_U records to fill the gaps in the S10 data set without applying any homogenization. At the AWS sites, SEB components are computed using an SEB model that uses as input hourly mean observations of wind, temperature, humidity and radiation components (Van den Broeke et al., 2011). The model evaluation also includes a comparison with accumulation measurements collected at 87 sites (Fig. 1, yellow dots). This data set is based on a compilation of deep snow pit and firn core measurements presented in Bales et al. (2001, 2009), selected for the period 1979-2012, when temporal overlap occurs between model and observations.

To compare model results to observations, we apply different selection methods in the ablation and accumulation zones of the GrIS. In the accumulation zone, modelled SMB is obtained by selecting the closest RACMO2 grid cell. Due to significant dependence of ablation terms on elevation, modelled SMB and SEB components were retrieved by successively selecting the nearest grid cell and then applying an altitude correction. To do so, we select a grid cell, among the closest pixel and its eight adjacent neighbours, which minimizes the elevation bias between the model and the stations.

\section{Changes in SMB components}

\subsection{SMB change pattern}

Figure 2 shows (a) RACMO2.3 average SMB (1990-2012) and (b) the difference in SMB between RACMO2.3 and RACMO2.1. Both model versions simulate a qualitatively realistic SMB field, with a narrow ablation zone fringing the ice sheet (Fig. 2). The ablation zone is widest ( $100-150 \mathrm{~km})$ in the south-west and north-east, but too narrow in the southeast to be resolved at a resolution of $11 \mathrm{~km}$; in this part of the ice sheet, the steep topography and high precipitation rates induce a large SMB gradient, resulting in an ablation zone only a few kilometres wide.

The SMB fields from RACMO2.1 and RACMO2.3 are qualitatively similar, but two patterns of difference can be discerned (Fig. 2b). First, a large-scale pattern with lower SMB in the west and higher SMB in the east results in enhanced longitudinal SMB gradients across the main topographical divide. The negative SMB change becomes gradually more pronounced towards the southern and south-eastern ice sheet, while the positive anomalies peak in the east. This large-scale pattern can be attributed to changes in the general circulation over the GrIS, as developed in Sect. 3.2.

Secondly, superimposed on this large-scale pattern, Fig. $2 b$ shows pronounced positive SMB changes that are spatially restricted to the ablation and lower accumulation zones of the south-western and north-eastern ice sheet. These regional changes can be ascribed to enhanced summer snowfall in RACMO2.3, following the revised rainfall-to-snowfall partitioning. These changes are discussed in detail in Sect. 3.3. 


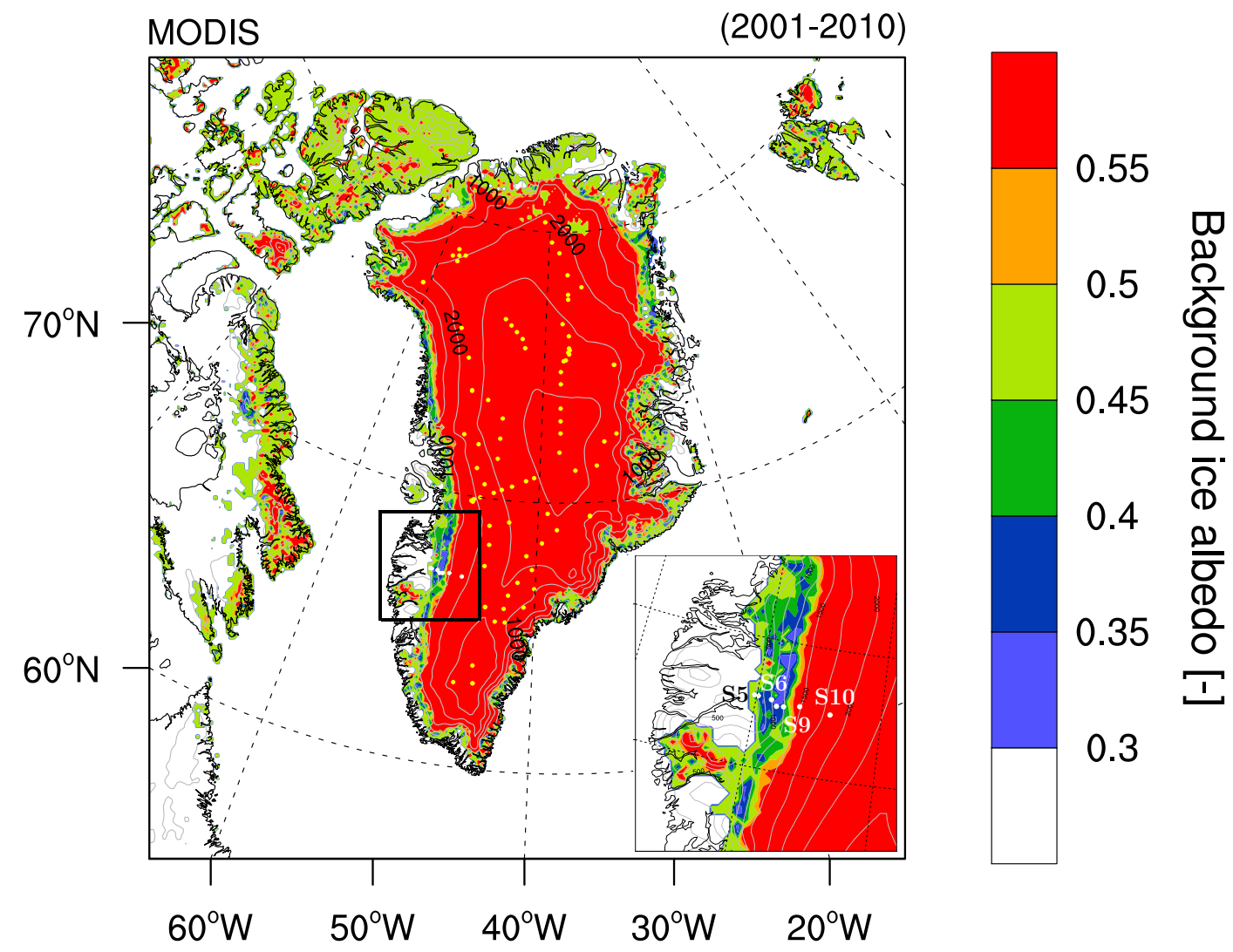

Figure 1. MODIS background ice albedo prescribed in RACMO2.3. The RACMO2 integration domain is displayed as well as the location of the K-transect (white dots, see also inset) and accumulation zone sites (yellow dots).

\subsection{Large-scale precipitation changes}

The average mid-tropospheric circulation at $500 \mathrm{hPa}$ is directed from south-west to north-east over Greenland (Fig. 3a), resulting in a large-scale negative precipitation gradient in the same direction. In addition, the proximity of the polar front, which predominantly produces easterly flow to its north, causes depressions to propagate eastward towards southern Greenland. This leads to a pronounced topographically forced precipitation maximum along the south-eastern coast.

Relative to RACMO2.1, RACMO2.3 is 0.1 to $0.3{ }^{\circ} \mathrm{C}$ colder in the upper troposphere (above $500 \mathrm{hPa}$, not shown). Among other processes, reduced upper-air condensation, attributed to the introduction of ice supersaturation in the updated physics, contributes to this cooling. Moreover, a lowering of the $500 \mathrm{hPa}$ geopotential height is modelled over the ice sheet with a minimum situated over coastal southeast Greenland (Fig. 3b). The resulting cyclonic circulation anomaly results in stronger onshore flow and increased precipitation in the north-eastern GrIS and a decrease in the north-western ice sheet, on the lee side of the main divide. In south Greenland, RACMO2.3 simulates decreased precipitation with respect to the previous model version; this is related to enhanced north-westerly advection of colder and drier air masses on the western side of the divide, more frequent offshore katabatic circulation and consequently weakened onshore flow to the east (Noël et al., 2014).

The large-scale circulation anomaly also reduces evaporation over the north Atlantic Ocean, by up to $200 \mathrm{mmWE}$ per year (not shown). Moreover, because condensation in the updated scheme is enhanced for moderately cold conditions $\left(<10^{\circ} \mathrm{C}\right)$, precipitation over the ocean is enhanced, further limiting precipitation in coastal south-east Greenland. Precipitation differences locally reach $25 \%$, and integrated over the GrIS the average 1990-2012 precipitation is reduced by $6 \%$, from $741 \mathrm{Gt} \mathrm{yr}^{-1}$ in RACMO2.1 to $698 \mathrm{Gt} \mathrm{yr}^{-1}$ in RACMO2.3. Note that the erratic box-like pattern in Fig. 3b results from an error in the meridional momentum advection scheme in RACMO2.1, which is solved in the current formulation.

\subsection{Summer snowfall events: the snow-albedo-melt feedback}

Owing to an increase of the cloud water-to-snowfall conversion coefficient, the revised physics in RACMO2.3 favours solid precipitation at the expense of liquid precipitation, especially for cloud temperatures between -7 and $-1^{\circ} \mathrm{C}$. In 


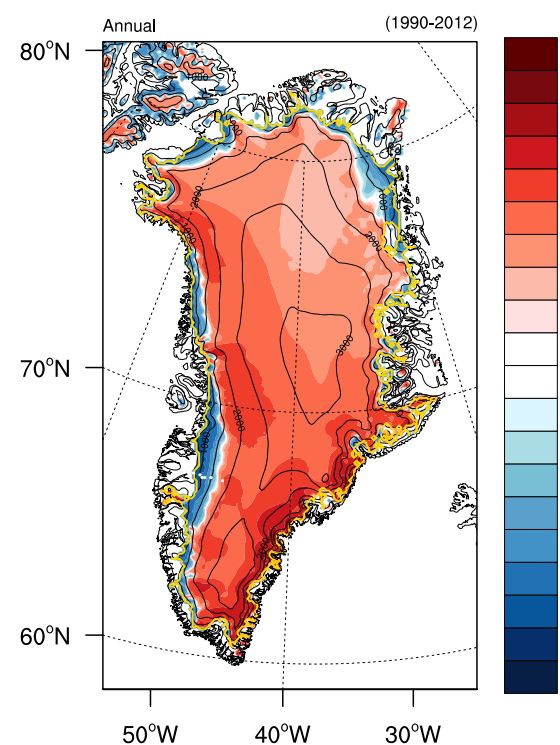

(a) RACMO2.3

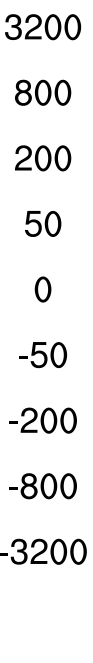

800
200
50
0
-50
-200
-800
-3200

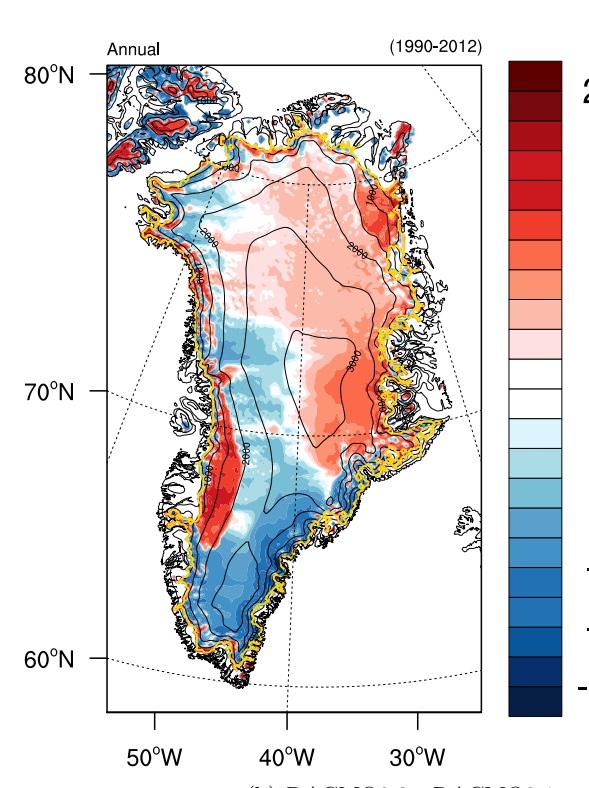

2560

640

160

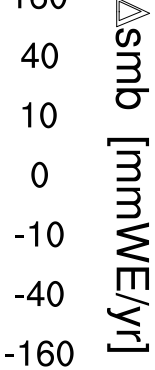

$-640$

$-2560$

Figure 2. (a) Mean annual SMB (mmWE $\mathrm{yr}^{-1}$ ) in RACMO2.3; (b) change in mean annual SMB (mmWE yr ${ }^{-1}$ ) between $\mathrm{RACMO}^{2.3}$ and RACMO2.1 (1990-2012). The ice sheet margin is displayed in yellow.

winter this has no major impact on the rainfall/snowfall ratio because the air temperature remains mostly below the solid precipitation threshold. In summer (JJA), however, RACMO2.3 predicts locally enhanced snowfall (10$40 \mathrm{mmWE}$ ), notably in south-west, north-east and northwest Greenland (Fig. 4a). These regional changes are accompanied by an equivalent decrease in rainfall (Fig. 4b), so we conclude that they result from the updated precipitation scheme. The reduced summer snowfall in the centre and south-east and the increase in east Greenland are not compensated by opposite and equivalent rainfall changes; here, precipitation changes are caused by the circulation change discussed in Sect. 3.2.

The regions experiencing increased summer snowfall coincide with positive changes in JJA surface albedo (Fig. 4c). The impact of summer snowfall on albedo is largest in the ablation zone, where the amount of absorbed shortwave radiation is reduced by a factor of $\sim 3$ when dark bare ice (albedo $\sim 0.30-0.55$ ) is covered by fresh snow (albedo $\sim 0.85$ ). As a consequence, meltwater runoff, which in RACMO2 is assumed to occur instantaneously over bare ice, is also substantially reduced (Fig. 4d). Note that this reduction in runoff (40-160 mmWE) significantly exceeds in magnitude the snowfall anomaly in Fig. 4a (5-30 mmWE), stressing the importance of the snow-albedo-melt feedback mechanism, in line with previously published results for valley glaciers (Greuell and Oerlemans, 1986). The pronounced runoff reductions are mirrored in the map of SMB change (Fig. 2b).

\section{Evaluation using observational data}

\subsection{SEB evaluation along the K-transect}

In this section, we compare modelled and observed monthly mean SEB components (2004-2012) along the K-transect, conveniently situated in a region of west Greenland where there are significant differences in SMB between the two model versions (Fig. 2b). We adopted the convention of positive energy fluxes when directed towards the surface. The melt flux $\left(\mathrm{M}, \mathrm{W} \mathrm{m}^{-2}\right)$ is given by:

$$
\begin{aligned}
\mathrm{M}= & \mathrm{SWd}+\mathrm{SWu}+\mathrm{LW}_{\mathrm{d}}+\mathrm{LWu}+\mathrm{SHF}+\mathrm{LHF}+\mathrm{Gs} \\
& \mathrm{SW}_{\mathrm{n}}+\mathrm{LW}_{\mathrm{n}}+\mathrm{SHF}+\mathrm{LHF}+\mathrm{Gs},
\end{aligned}
$$

where SWd and SWu are the downward and upward shortwave radiation fluxes $\left(\mathrm{W} \mathrm{m}^{-2}\right) ; \mathrm{LW}_{\mathrm{d}}$ and $\mathrm{LWu}$ are the downward and upward longwave radiation fluxes $\left(\mathrm{W} \mathrm{m}^{-2}\right)$; SHF and LHF are the sensible and latent turbulent heat fluxes $\left(\mathrm{W} \mathrm{m}^{-2}\right)$; and $\mathrm{SW}_{\mathrm{n}}$ and $\mathrm{LW}_{\mathrm{n}}$ are the net short/longwave radiation fluxes $\left(\mathrm{W} \mathrm{m}^{-2}\right)$. Gs is the subsurface heat flux $\left(\mathrm{W} \mathrm{m}^{-2}\right)$ which remains small, i.e., not exceeding $-1.43 \mathrm{~W} \mathrm{~m}^{-2} \mathrm{yr}^{-1}$, and is not further discussed in this paper.

SEB data from the AWS at S6 are not used because of gaps in the time series. Figure 5 and Tables $1-3$ show observed and modelled monthly mean SEB components, surface albedo, melt energy and the differences for the period 2004-2012 (S5 and S9) and 2010-2012 (S10). For station S9, a distinction is made between the sub-periods 2004-2008 and 2009-2012; this is deemed relevant because of the significantly warmer summer conditions near the surface and in the upper atmosphere during the latter period. Figure 5a, c, e and g show that 


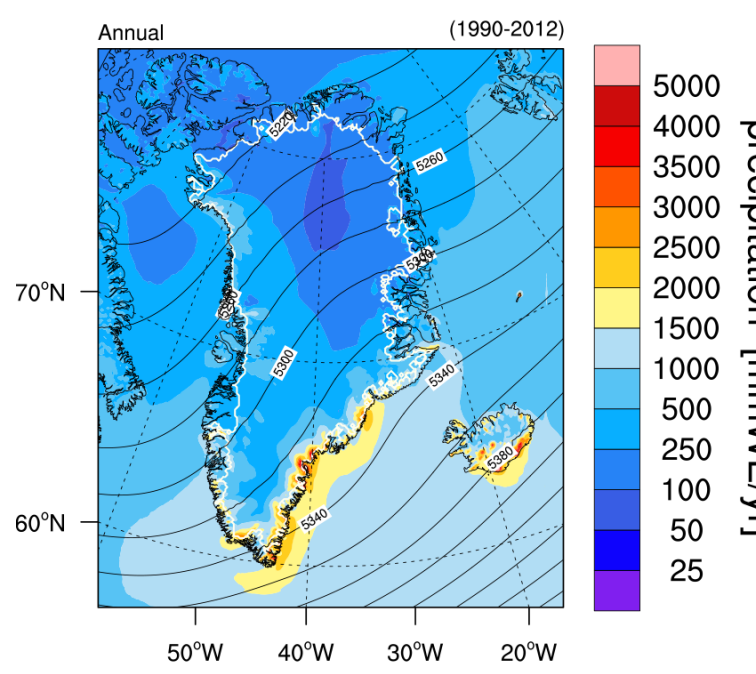

(a) RACMO2.3

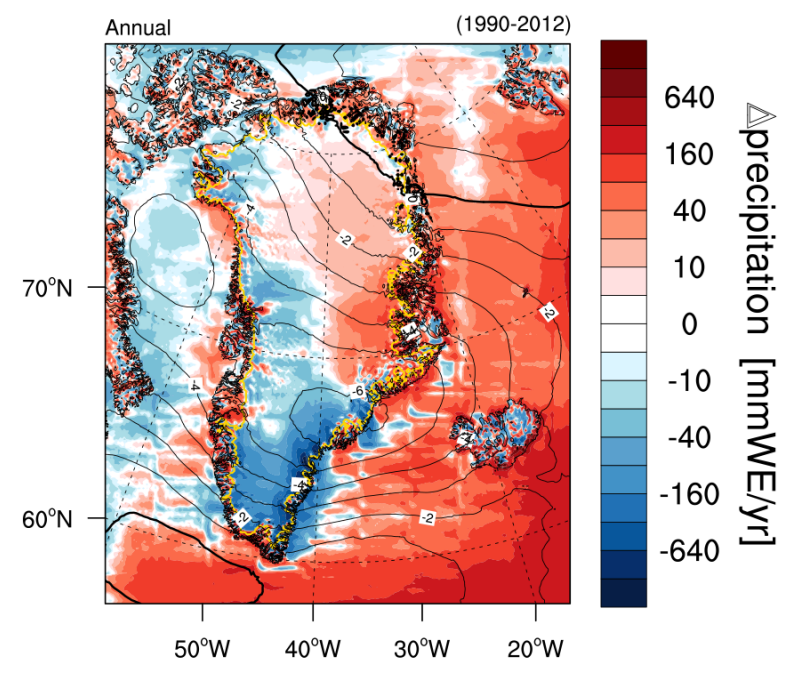

(b) RACMO2.3 - RACMO2.1

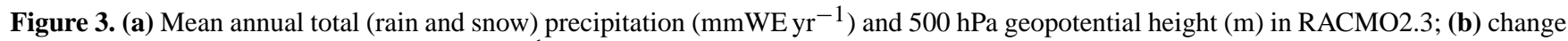
in mean annual total precipitation ( $\mathrm{mmWE} \mathrm{yr}^{-1}$ ) and $500 \mathrm{hPa}$ geopotential height (m) between RACMO2.3 and RACMO2.1 (1990-2012).

there is qualitative agreement between the modelled and observed seasonal cycle of the SEB in the ablation, equilibrium and accumulation zones. However, important biases remain, as discussed below.

\subsubsection{Ablation zone (S5)}

At station S5, Table 1 shows that both RACMO2 versions significantly overestimate $\mathrm{SWd}$ and underestimate $\mathrm{LW}_{\mathrm{d}}$, even more so in RACMO2.3, which is indicative of underestimated cloud optical thickness. In combination with underestimated ice albedo (Fig. 5b) this leads to significantly overestimated net shortwave radiation $\left(\mathrm{SW}_{\mathrm{n}}\right)$ in summer (Fig. 5a). On the other hand, RACMO2 underestimates the large summertime SHF values at S5, although this is improved in RACMO2.3 (Table 1). The reason is that station S5 has a complex topography: neither the summertime advection of warm tundra air over the glacier tongue that protrudes onto the tundra, leading to underestimated air temperature (Table 1), nor the high surface roughness at the marginal glaciers (Smeets and van den Broeke, 2008) are well-described at $11 \mathrm{~km}$ resolution. This leads to underestimated surface-to-air gradients of temperature and wind, and hence to too small SHF. This does not strongly affect LHF, which remains close to zero at S5. The net effect on melt energy is a negative bias (Fig. 5b) that has become smaller in RACMO2.3 (from 18 to $13 \%$ ), albeit owing to significant error compensation.

\subsubsection{Around the equilibrium line (S9)}

At S9, RACMO2.3 reduces the bias in most SEB components (Table 2). The 2 metre temperature bias has almost vanished, which has improved the representation of SHF. Despite a no- table improvement of winter $\mathrm{LW}_{\mathrm{n}}$ (not shown), $\mathrm{LW}_{\mathrm{d}}$ remains underestimated (Table 2). Average biases in SWd, SWu and $\mathrm{SW}_{\mathrm{n}}$ are greatly reduced in RACMO2.3. In RACMO2.1, the average melt bias was small at S9 (Table 2), but this was the result of overestimated melt in the period 2004-2008, and underestimated melt in 2009-2012 (Fig. 5d and f). For the period 2004-2008, enhanced summer snowfall has increased surface albedo in RACMO2.3 (Fig. 6a), which leads to an overall improved representation and a clearly reduced melt bias (Fig. 5d). In contrast, simulated summer snowfall has not considerably changed at station S9 for the period 20092012 (Fig. 6b) and biases in albedo and melt energy have persisted (Fig. 5d and f). The explanation is that summer atmospheric temperatures in 2009-2012 were too high for the new precipitation scheme to enhance snowfall.

The bias in surface albedo between model and observations (Fig. 5f) can be explained by the too high prescribed bare ice albedo (Fig. 1). No ice albedo could be derived from MODIS imagery for this location, in which case we prescribe a constant ice albedo of 0.55 . However, in recent warm summers, the surface at $\mathrm{S} 9$ showed lower albedo values of $\sim 0.43$ and $\sim 0.45$ in 2010 and 2012, respectively. As a consequence, both RACMO2 versions fail to capture this ongoing decline of summer ice albedo.

\subsubsection{Accumulation zone (S10)}

At S10, biases in shortwave fluxes are greatly reduced but again the negative $\mathrm{LW}_{\mathrm{d}}$ bias persists (Table 3 ). In winter this is mainly compensated by an overestimated SHF, but not so in summer (Fig. 5g). In June and July, the representation of albedo has improved, but in August albedo is now overestimated. $\mathrm{SW}_{\mathrm{n}}$ remains somewhat too large. However, since 


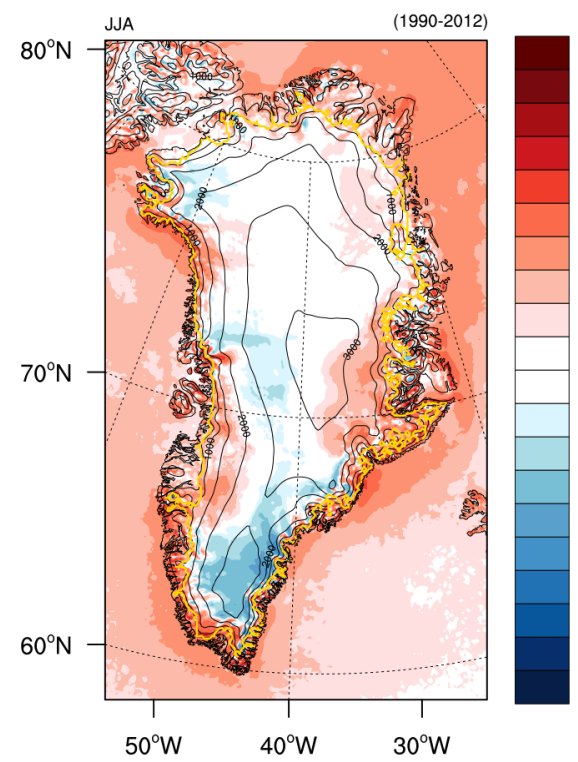

(a) JJA Snowfall

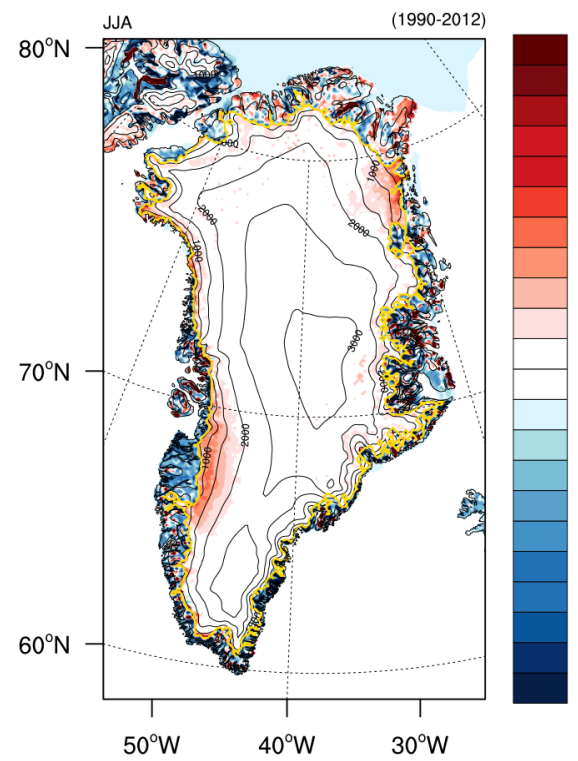

(c) JJA Albedo
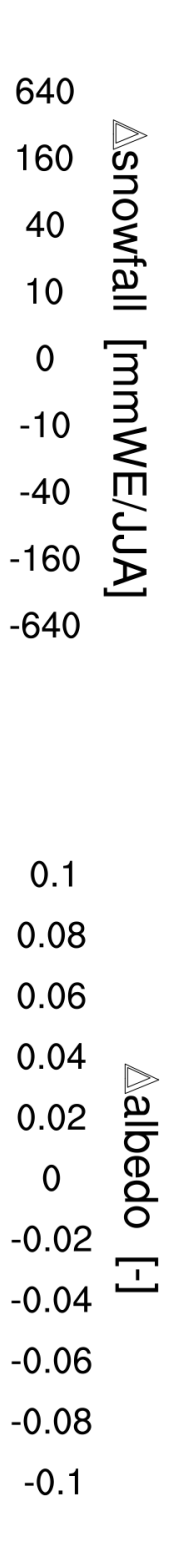

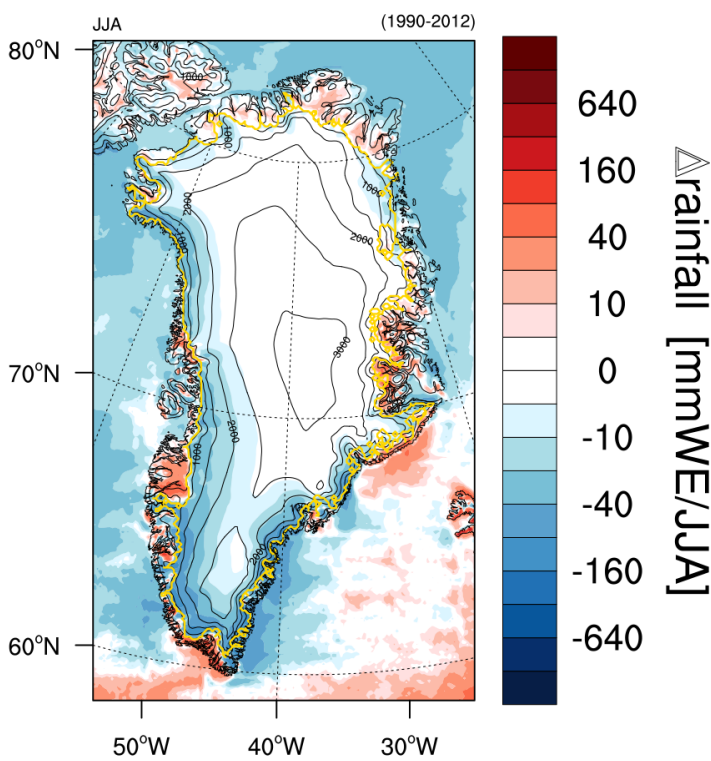

(b) JJA Rainfall

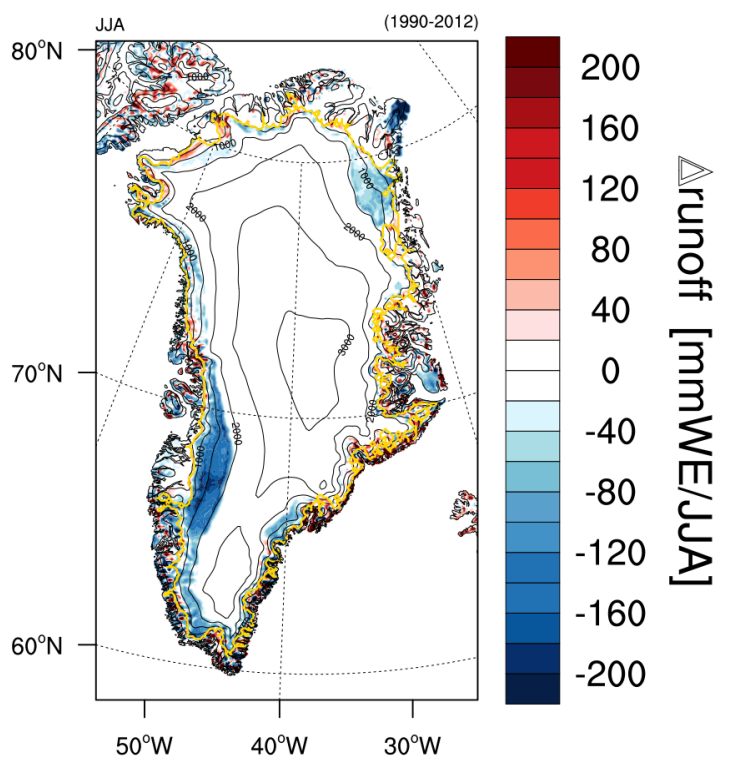

(d) JJA Runoff

Figure 4. Change in JJA mean (a) snowfall $\left(\mathrm{mmWE} \mathrm{JJA}^{-1}\right.$ ), (b) rainfall $\left(\mathrm{mmWE} \mathrm{JJA}^{-1}\right.$ ), (c) surface albedo and (d) runoff (mmWE JJA ${ }^{-1}$ ) between RACMO2.3 and RACMO2.1 (1990-2012).

$\mathrm{LW}_{\mathrm{n}}$ is underestimated, the errors in melt energy are less than $10 \mathrm{~W} \mathrm{~m}^{-2}$ (Fig. 5h). The lower accumulation zone responds similarly to station S9 during 2004-2008 but with a reduced surface albedo sensitivity to summer snowfall, because snow metamorphism is slower in this colder area and snow wetting occurs less frequently.

The generally improved representation of surface snow albedo is attributed to enhanced summer snowfall in RACMO2.3 (see Sect. 3.3), thickening the melting snow cover and allowing the snow layer to persist longer over bare ice areas in summer. As a result, snowmelt decreases, further delaying snow cover disappearance and maintaining the surface albedo high until summer snowfall events cease (Fig. 6a). The summer surface albedo increase is further reinforced by a drop in cloud cover. This process reduces $\mathrm{LW}_{\mathrm{d}}$, also decreasing snowmelt at station S9 (Fig. 5d).

\subsection{SMB evaluation}

\subsubsection{Temporal SMB variability}

Table 4 compares time series of modelled and measured annual SMB values (1990-2012) collected at seven stake sites, 

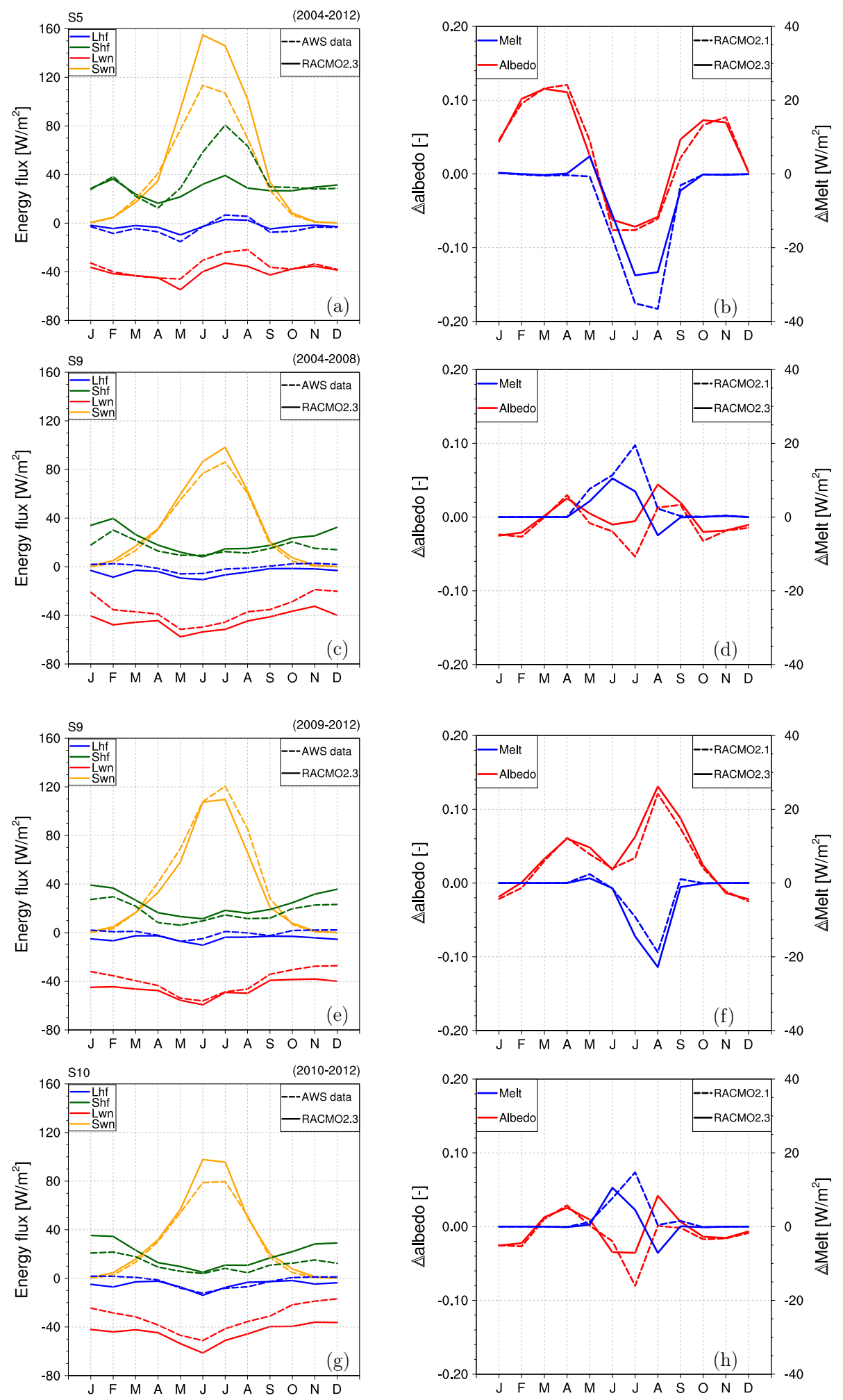

Figure 5. Observed and modelled turbulent and net shortwave/longwave fluxes ( $\mathrm{W} \mathrm{m}^{-2}$ ) at station (a) S5 for 2004-2012, (c) S9 for 20042008, (e) S9 for 2009-2012 and (g) S10 for 2010-2012; difference in modelled and observed surface albedo and surface melt energy (W $\mathrm{m}^{-2}$ ) at stations (b) S5, (d) S9, (f) S9 and (h) S10 for the same periods. 


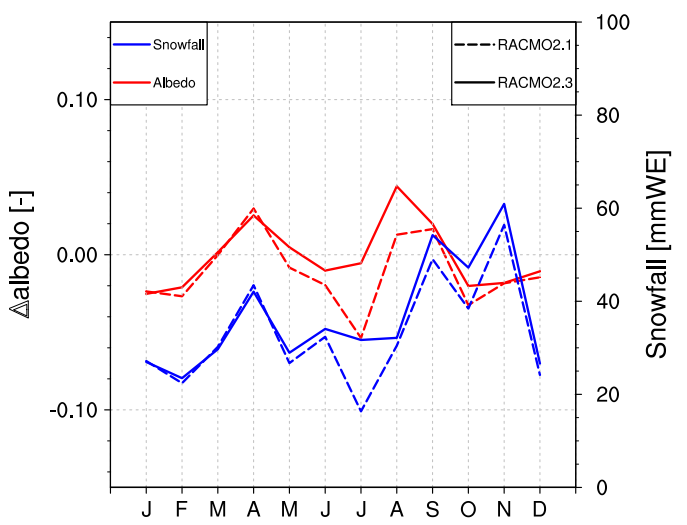

(a) S9 (2004-2008)

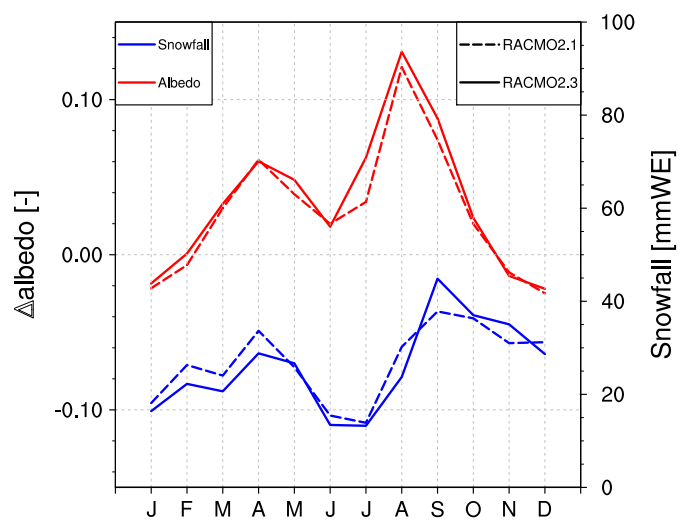

(b) S9 (2009-2012)

Figure 6. Differences in monthly mean surface albedo between models and S9 measurements, and monthly mean modelled snowfall for the periods (a) 2004-2008 and (b) 2009-2012.

ranging from station S5 in the lower ablation zone to station S10 in the accumulation zone (Fig. 1, white dots). Figure 7 shows these time series for RACMO2.3 at four sites. The lowermost stake $\mathrm{S} 4$ ( $400 \mathrm{~m}$ a.s.l.) is excluded from the analysis because it is not well resolved by the model ice sheet mask. At all sites except S10, the agreement improves in RACMO2.3, expressed as lower biases and a higher percentage of variance explained $\left(r^{2}\right.$, Table 4). At S10, SMB interannual variability is not well captured, but it must be stated that stake SMB measurements have limited accuracy in the percolation zone due to uncertainties in the snow density and subsurface refreezing.

\subsubsection{Spatial SMB variability}

Figure 8 compares modelled and observed SMB in the GrIS accumulation zone retrieved from snow pits and firn cores (Fig. 1, yellow dots). In the accumulation zone, the difference in modelled SMB between both RACMO2 versions (Fig. 2b) is mostly driven by changes in precipitation (Fig. 3b). Relative to the previous model version, RACMO2.3 simulates wetter conditions in central and north-east Greenland whereas the southern region shows reduced precipitation. These changes improve the agreement with accumulation measurements at most locations in the accumulation zone (Fig. 8).

Table 4 and Fig. 9 compare modelled and observed Ktransect average SMB (1991-2012) as deduced from annual stake measurements. Fig. 9 also shows the prescribed MODIS background albedo (green dots, scale on right axis). The covariance of ice albedo with modelled SMB once more underlines the importance of ice albedo for the ablation zone SMB (Van Angelen et al., 2012). Again it must be noted that the stake sites are not necessarily representative for a larger region, e.g., for the area of a model grid cell $\left(\sim 120 \mathrm{~km}^{2}\right)$.

In the lower ablation zone, between 500 to $800 \mathrm{~m}$ a.s.l., RACMO2.3 simulates lower (more negative) SMB values than RACMO2.1, which better matches observations. This improvement can be ascribed to a smaller bias in melt energy (Table 1) and hence a more realistic runoff. Correcting the persistent overestimation of SMB between 500 and $800 \mathrm{~m}$ a.s.l. will require a better representation of SHF which, in combination with $\mathrm{SWd}$ and $\mathrm{LW}_{\mathrm{d}}$, is a primary factor governing melt rate in the lower ablation zone. For elevations between $800 \mathrm{~m}$ and the equilibrium line at about $1500 \mathrm{~m}$ a.s.l., RACMO2.3 simulates higher SMB values compared to RACMO2.1, resulting mainly from reduced runoff following enhanced summer snowfall through the snow-albedomelt feedback. The absence of rapid SMB fluctuations in the model between $1400 \mathrm{~m}$ a.s.l. and the equilibrium line is clearly related to the fixed upper threshold (0.55) of bare ice albedo prescribed in RACMO2 (Van Angelen et al., 2012). In the accumulation zone (above $1500 \mathrm{~m}$ ), enhanced snowfall and less runoff have significantly improved the agreement with the K-transect stake observations.

An alternative way to assess model performance is to quantify SMB gradients, here determined by simple least-squares fitting of a linear function. This yields $3.15 \pm 0.22 \mathrm{mmWE} \mathrm{yr}^{-1} \mathrm{~m}^{-1}$ for the observations and $2.73 \pm 0.09$ and $2.91 \pm 0.07 \mathrm{mmWE} \mathrm{yr}^{-1} \mathrm{~m}^{-1}$ for RACMO2.1 and RACMO2.3, respectively; in the updated model, the deviation from the observed gradient has thus decreased from 0.42 to $0.24 \mathrm{mmWE} \mathrm{yr}^{-1} \mathrm{~m}^{-1}$, a $43 \%$ improvement of the SMB gradient representation.

\section{Conclusions}

An updated physics package has been implemented in the regional climate model RACMO2.3. Among other changes, the rainfall-to-snowfall conversion has been revised and an ice supersaturation parameterization included to favour solid over liquid precipitation in summer and reduce the overestimated coastal cloud cover and precipitation simulated in pre- 
Table 1. Modelled and observed annual mean SEB components and statistics of the differences (2004-2012) at station S5 (67 $06^{\prime} \mathrm{N}$, $50^{\circ} 05^{\prime} \mathrm{W}, 490 \mathrm{~m}$ a.s.1) in the ablation zone. Statistics include means of measurements collected at S5, model bias (RACMO2 - observations), standard deviation of the bias, Root Mean Square Difference (RMSD) of the bias as well as determination coefficient between RACMO2 and S5 observations. Fluxes are set positive for downward radiation.

\begin{tabular}{|c|c|c|c|c|c|c|c|c|c|c|}
\hline \multirow{2}{*}{$\begin{array}{l}\text { AWS } \\
\text { Variable }\end{array}$} & \multirow{2}{*}{$\begin{array}{l}\text { S5 } \\
\text { unit }\end{array}$} & \multirow{2}{*}{$\begin{array}{l}\text { OBS } \\
\text { mean }\end{array}$} & \multicolumn{4}{|c|}{ RACMO2.1 } & \multicolumn{4}{|c|}{ RACMO2.3 } \\
\hline & & & bias & $\sigma_{\text {bias }}$ & RMSD & $r^{2}$ & bias & $\sigma_{\text {bias }}$ & RMSD & $r^{2}$ \\
\hline $\mathrm{SW}_{\mathrm{d}}$ & $\mathrm{W} \mathrm{m}^{-2}$ & 108.7 & 16.3 & 18.7 & 24.8 & 0.98 & 26.2 & 20.8 & 33.4 & 0.99 \\
\hline $\mathrm{SW}_{\mathrm{u}}$ & $\mathrm{W} \mathrm{m}^{-2}$ & -69.8 & -8.5 & 16.2 & 18.3 & 0.95 & -15.4 & 18.4 & 24.0 & 0.93 \\
\hline $\mathrm{LW}_{\mathrm{d}}$ & $\mathrm{W} \mathrm{m}^{-2}$ & 244.8 & -17.2 & 8.6 & 19.2 & 0.97 & -18.4 & 6.9 & 19.7 & 0.97 \\
\hline $\mathrm{LW}_{\mathrm{u}}$ & $\mathrm{W} \mathrm{m}^{-2}$ & -280.6 & 15.4 & 9.6 & 18.1 & 0.98 & 13.9 & 8.3 & 16.2 & 0.98 \\
\hline SHF & $\mathrm{W} \mathrm{m}{ }^{-2}$ & 37.4 & -11.8 & 19.7 & 23.0 & 0.21 & -8.9 & 17.3 & 19.4 & 0.46 \\
\hline LHF & $\mathrm{W} \mathrm{m}^{-2}$ & 4.1 & -2.6 & 5.3 & 5.9 & 0.60 & -1.6 & 5.0 & 5.3 & 0.66 \\
\hline MELT & $\mathrm{W} \mathrm{m}^{-2}$ & 42.8 & -7.8 & 17.7 & 19.4 & 0.96 & -5.4 & 14.2 & 15.2 & 0.97 \\
\hline ALB & $(-)$ & 0.73 & 0.03 & 0.09 & 0.09 & 0.73 & 0.03 & 0.08 & 0.09 & 0.74 \\
\hline$T_{2 \mathrm{~m}}$ & ${ }^{\circ} \mathrm{C}$ & -6.0 & -2.7 & 1.7 & 3.2 & 0.99 & -2.3 & 1.1 & 2.6 & 0.99 \\
\hline
\end{tabular}

Table 2. Same as Table 1 but for station $\mathrm{S} 9\left(67^{\circ} 03^{\prime} \mathrm{N}, 48^{\circ} 15^{\prime} \mathrm{W}, 1520 \mathrm{~m}\right.$ a.s.l) close to the equilibrium line. SEB components include annual mean data for period 2004-2012.

\begin{tabular}{ll|r|rrrr|rrrr}
\hline \multirow{2}{*}{$\begin{array}{l}\text { AWS } \\
\text { Variable }\end{array}$} & S9 & OBit & mean & bias & \multicolumn{3}{|c}{ RACMO2.1 } & \multicolumn{4}{|c}{ RACMO2.3 } \\
& & & RMSD & $r^{2}$ & bias & $\sigma_{\text {bias }}$ & RMSD & $r^{2}$ \\
\hline $\mathrm{SW}_{\mathrm{d}}$ & $\mathrm{W} \mathrm{m}^{-2}$ & 139.8 & -9.5 & 11.4 & 14.8 & 0.994 & 3.2 & 6.6 & 7.3 & 0.997 \\
$\mathrm{SW}_{\mathrm{u}}$ & $\mathrm{W} \mathrm{m}^{-2}$ & -105.9 & 9.0 & 12.8 & 15.7 & 0.99 & -3.3 & 9.1 & 9.7 & 0.99 \\
$\mathrm{LW}_{\mathrm{d}}$ & $\mathrm{W} \mathrm{m}^{-2}$ & 219.1 & -9.1 & 12.4 & 15.4 & 0.92 & -9.4 & 9.1 & 13.1 & 0.94 \\
$\mathrm{LW}_{\mathrm{u}}$ & $\mathrm{W} \mathrm{m}^{-2}$ & -256.1 & -0.2 & 4.5 & 4.5 & 0.99 & 1.1 & 3.9 & 4.1 & 0.99 \\
$\mathrm{SHF}$ & $\mathrm{W} \mathrm{m}^{-2}$ & 16.5 & 9.8 & 7.5 & 12.4 & 0.61 & 6.6 & 5.8 & 8.8 & 0.69 \\
$\mathrm{LHF}$ & $\mathrm{W} \mathrm{m}^{-2}$ & 0.3 & 4.3 & 3.1 & 5.3 & 0.34 & 4.4 & 3.4 & 5.6 & 0.28 \\
$\mathrm{MELT}$ & $\mathrm{W} \mathrm{m}^{-2}$ & 12.6 & 1.0 & 9.2 & 9.2 & 0.86 & -0.6 & 8.3 & 8.3 & 0.89 \\
$\mathrm{ALB}$ & $(-)$ & 0.83 & 0.01 & 0.05 & 0.05 & 0.79 & 0.01 & 0.04 & 0.05 & 0.82 \\
$T_{2 \mathrm{~m}}$ & ${ }^{\circ} \mathrm{C}$ & -13.0 & 0.6 & 0.9 & 1.1 & 0.99 & 0.1 & 0.7 & 0.7 & 0.99 \\
\hline
\end{tabular}

Table 3. Same as Table 1 but for station $\mathrm{S} 10\left(67^{\circ} 00^{\prime} \mathrm{N}, 47^{\circ} 01^{\prime} \mathrm{W}, 1850 \mathrm{~m}\right.$ a.s.l $)$ in the accumulation zone. SEB components include annual mean data for the period 2010-2012.

\begin{tabular}{|c|c|c|c|c|c|c|c|c|c|c|}
\hline \multirow{2}{*}{$\begin{array}{l}\text { AWS } \\
\text { Variable }\end{array}$} & \multirow{2}{*}{$\begin{array}{l}\text { S10 } \\
\text { unit }\end{array}$} & \multirow{2}{*}{$\begin{array}{l}\text { OBS } \\
\text { mean }\end{array}$} & \multicolumn{4}{|c|}{ RACMO2.1 } & \multicolumn{4}{|c|}{ RACMO2.3 } \\
\hline & & & bias & $\sigma_{\text {bias }}$ & RMSD & $r^{2}$ & bias & $\sigma_{\text {bias }}$ & RMSD & $r^{2}$ \\
\hline $\mathrm{SW}_{\mathrm{d}}$ & $\mathrm{W} \mathrm{m}^{-2}$ & 141.5 & -11.8 & 12.9 & 17.5 & 0.994 & 1.8 & 7.7 & 7.9 & 0.997 \\
\hline $\mathrm{SW}_{\mathrm{u}}$ & $\mathrm{W} \mathrm{m}^{-2}$ & -113.8 & 15.3 & 18.0 & 23.7 & 0.98 & 2.3 & 12.1 & 12.4 & 0.99 \\
\hline $\mathrm{LW}_{\mathrm{d}}$ & $\mathrm{W} \mathrm{m}^{-2}$ & 220.4 & -14.1 & 12.3 & 18.7 & 0.92 & -14.1 & 8.9 & 16.7 & 0.93 \\
\hline $\mathrm{LW}_{\mathrm{u}}$ & $\mathrm{W} \mathrm{m}^{-2}$ & -252.5 & 0.6 & 5.2 & 5.2 & 0.98 & 1.6 & 4.2 & 4.5 & 0.99 \\
\hline SHF & $\mathrm{W} \mathrm{m}^{-2}$ & 11.9 & 11.6 & 7.7 & 13.9 & 0.64 & 7.9 & 5.7 & 9.8 & 0.74 \\
\hline LHF & $\mathrm{W} \mathrm{m}^{-2}$ & 2.7 & 1.5 & 3.8 & 4.1 & 0.41 & 2.5 & 4.0 & 4.7 & 0.39 \\
\hline MELT & $\mathrm{W} \mathrm{m}^{-2}$ & 8.9 & 2.1 & 5.9 & 6.2 & 0.94 & 0.7 & 4.3 & 4.3 & 0.94 \\
\hline ALB & $(-)$ & 0.86 & -0.01 & 0.04 & 0.04 & 0.69 & -0.001 & 0.04 & 0.04 & 0.71 \\
\hline$T_{2 \mathrm{~m}}$ & ${ }^{\circ} \mathrm{C}$ & -14.6 & 1.0 & 1.4 & 1.7 & 0.98 & 0.5 & 1.0 & 1.1 & 0.99 \\
\hline
\end{tabular}


Table 4. Modelled and observed mean annual SMB $\left(\mathrm{mWE} \mathrm{yr}^{-1}\right)$ and statistics of the differences at $\mathrm{S} 5\left(67^{\circ} 06^{\prime} \mathrm{N}, 50^{\circ} 05^{\prime} \mathrm{W}, 490 \mathrm{~m}\right.$ a.s.l), $\mathrm{SHR}^{\circ}$ $\left(67^{\circ} 06^{\prime} \mathrm{N}, 49^{\circ} 56^{\prime} \mathrm{W}, 710 \mathrm{~m}\right.$ a.s.l), S6 (67 $05^{\prime} \mathrm{N}, 49^{\circ} 24^{\prime} \mathrm{W}, 1010 \mathrm{~m}$ a.s.l), S7 (66 $59^{\prime} \mathrm{N}, 4^{\circ} 09^{\prime} \mathrm{W}, 1110 \mathrm{~m}$ a.s. 1$), \mathrm{S}^{\prime}\left(67^{\circ} 00^{\prime} \mathrm{N}, 48^{\circ} 53^{\prime} \mathrm{W}\right.$, $1260 \mathrm{~m}$ a.s.l) and $\mathrm{S} 9\left(67^{\circ} 03^{\prime} \mathrm{N}, 48^{\circ} 15^{\prime} \mathrm{W}, 1520 \mathrm{~m}\right.$ a.s.l) over $1990-2012$; S10 $\left(67^{\circ} 00^{\prime} \mathrm{N}, 47^{\circ} 01^{\prime} \mathrm{W}, 1850 \mathrm{~m}\right.$ a.s.l) covers the period $1994-$ 2010 .

\begin{tabular}{l|r|rrrr|rrrr}
\hline Stakes & OBS. & \multicolumn{5}{|c|}{ RACMO2.1 } & \multicolumn{4}{|c}{ RACMO2.3 } \\
SMB & mean & bias & $\sigma_{\text {bias }}$ & RMSD & $r^{2}$ & bias & $\sigma_{\text {bias }}$ & RMSD & $r^{2}$ \\
\hline S5 & -3.7 & 1.0 & 0.5 & 1.1 & 0.36 & 0.7 & 0.4 & 0.8 & 0.49 \\
SHR & -3.1 & 0.4 & 0.5 & 0.6 & 0.41 & 0.3 & 0.4 & 0.5 & 0.53 \\
S6 & -1.7 & -0.8 & 0.6 & 1.0 & 0.25 & -0.7 & 0.6 & 0.9 & 0.28 \\
S7 & -1.5 & -0.7 & 0.4 & 0.9 & 0.59 & -0.6 & 0.4 & 0.7 & 0.66 \\
S8 & -0.8 & -0.7 & 0.4 & 0.8 & 0.55 & -0.4 & 0.4 & 0.5 & 0.64 \\
S9 & -0.1 & -0.4 & 0.2 & 0.5 & 0.73 & -0.2 & 0.2 & 0.3 & 0.80 \\
S10 & 0.3 & -0.03 & 0.2 & 0.2 & 0.34 & 0.2 & 0.1 & 0.3 & 0.25 \\
\hline
\end{tabular}

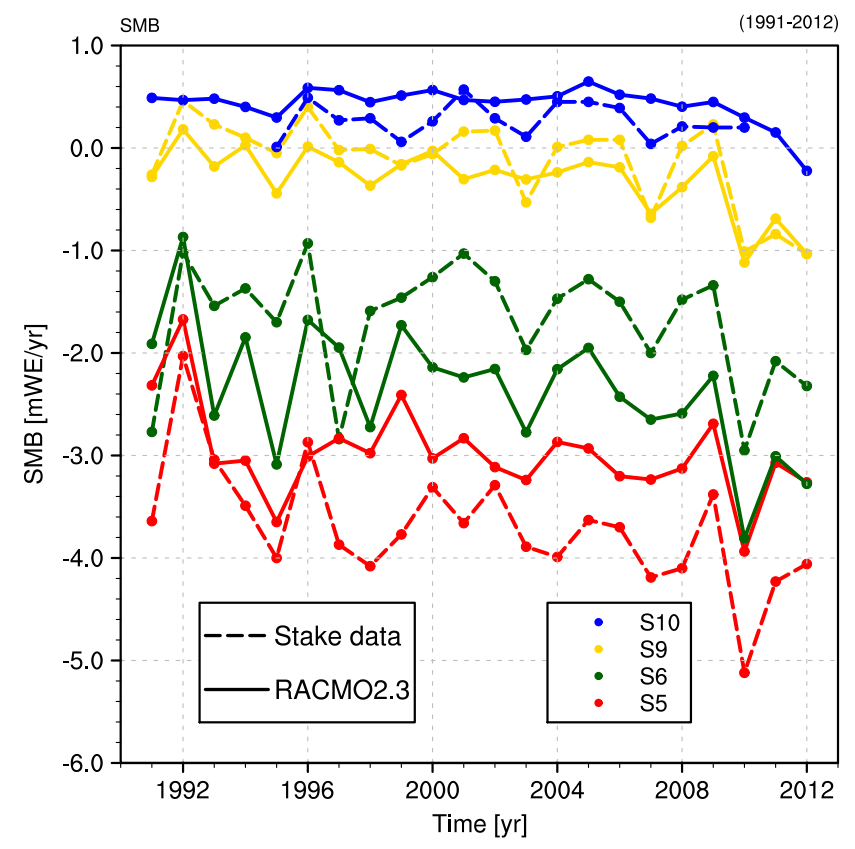

Figure 7. Time series of observed (AWS) and modelled (RACMO2.3 and 2.1) annual mean SMB along the K-transect

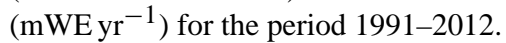

vious versions, respectively (Van de Berg et al., 2006). The subsequent increase in modelled summer snowfall has generally improved the representation of surface energy balance (SEB) and surface mass balance (SMB) along the K-transect in west Greenland. For SEB, these improvements are more pronounced in the lower accumulation zone, where summer temperatures are generally below zero. Close to the equilibrium line, SMB is especially sensitive to snowfall-induced fluctuations in surface albedo. The increase in summer snowfall enhances surface reflectivity, improving the modelled surface albedo in summer as well as SMB representation. However, in recent warm years (e.g. 2010 and 2012) rainfall prevailed even in the new formulation, and no improvement

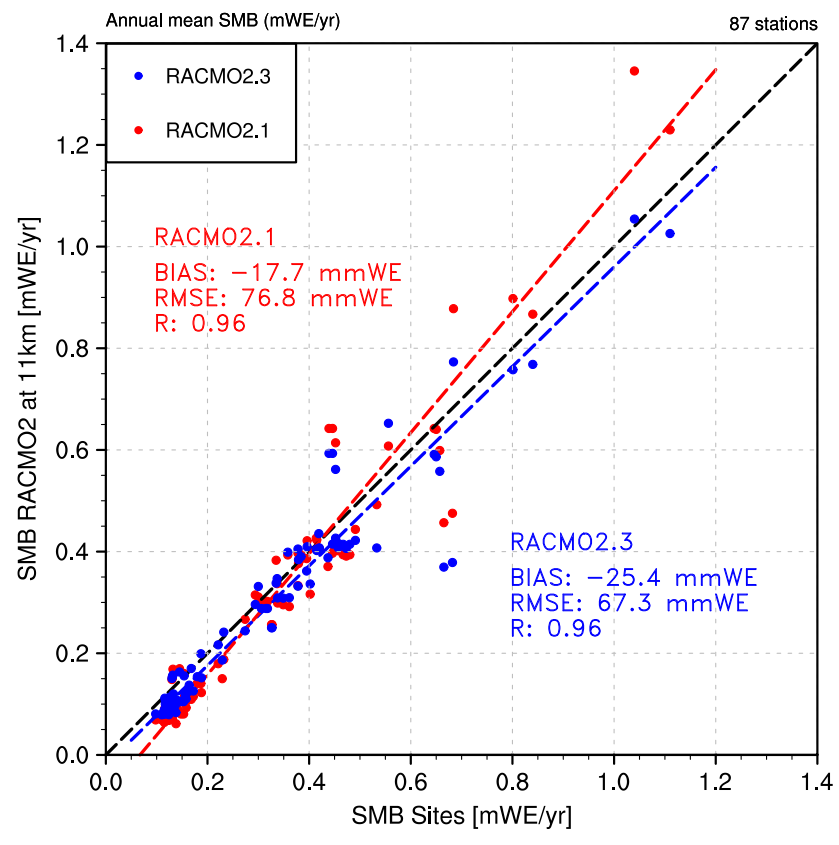

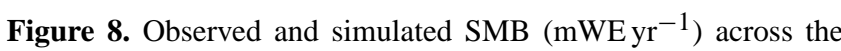
accumulation zone of the GrIS averaged for the period 1979-2012. The regression lines are displayed as dashed lines for RACMO2.3 (blue) and 2.1 (red). For observation locations, see yellow dots in Fig. 1.

was obtained. At station S5 in the lower ablation zone, summer albedo in RACMO2 is mainly determined by the prescribed MODIS ice albedo, due to near-continuous bare ice exposure. The updated physics in RACMO2.3 have considerably improved the modelled SMB gradient along the Ktransect when compared to ablation stake measurements, reducing the bias by $43 \%$.

Two remaining problems require particular attention in future model updates. Current RCMs still struggle to model the correct cloud cover and cloud type (ice/water) over the GrIS (Box et al., 2012). For instance, both RACMO2 and MAR 


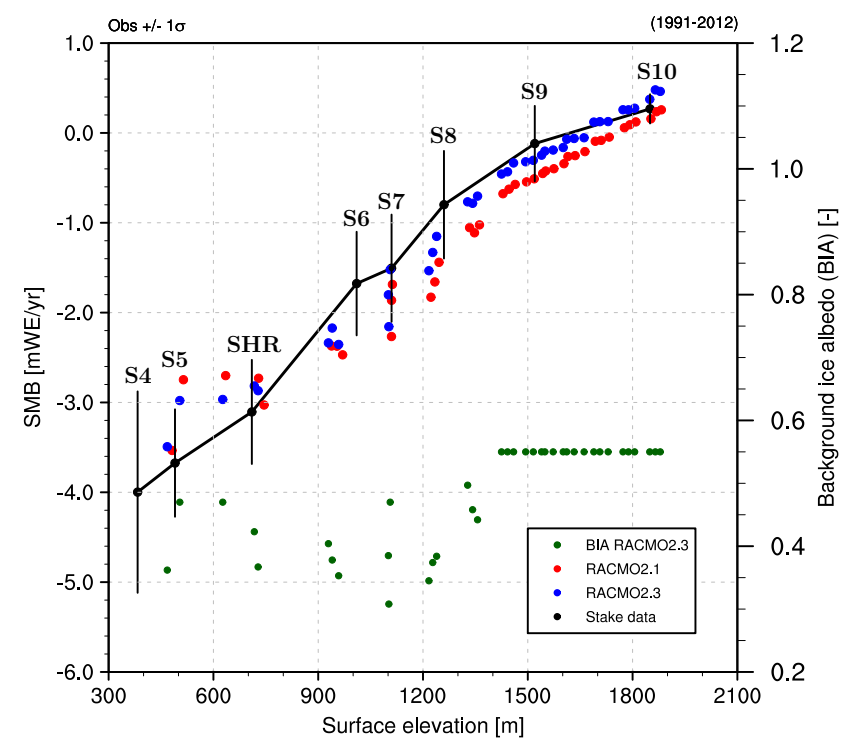

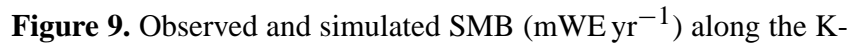
transect in west Greenland $\left(\sim 67^{\circ} \mathrm{N}\right)$, averaged for the period 19912012. The observed SMB (black dots) at S4, S5, SHR, S6, S7, S8, S9 and S10 are based on annual stake measurements. S10 observations cover 1994-2010. The black bars represent the standard deviation $( \pm 1 \sigma)$ around the 1991-2012 mean value. Modelled SMB at stake sites and intermediate locations are displayed for RACMO2.3 (blue dots) and RACMO2.1 (red dots). MODIS background ice albedo as prescribed in RACMO2.3, is depicted in green (axis on right).

models underestimate summer $\mathrm{LW}_{\mathrm{d}}$ and overestimate $\mathrm{SWd}$ due to an underestimated cloud optical thickness (Ettema et al., 2010; Fettweis et al., 2011). In fact, the inclusion of ice supersaturation in RACMO2.3 might aggravate this problem over the ablation zone, because, for inland-propagating air masses, this process delays cloud condensation to higher ice sheet elevations, as was also seen in simulations of Antarctic climate (Van Wessem et al., 2014). Evaluation of the modelled cloud properties and surface properties using CloudSAT/Calypso data will be addressed in a forthcoming paper.

Another revision that is simpler to implement is improvement of the background ice albedo, that is currently too low at the ice sheet margin. However, at this point, it is also important to realize that point AWS (SEB) and stake (SMB) measurements may not be representative for a wider area, especially for a spatially heterogeneous variable such as surface albedo. Sub-grid albedo variability should therefore become an important future topic of study. To assess the quality of the simulated SMB in the ablation zone elsewhere in Greenland, an evaluation of downscaled RACMO2.3 data against a much larger data set of ablation measurements, covering all sectors of the Greenland ice sheet, is currently being conducted.
Acknowledgements. B. Noël, W. J. van de Berg, P. Kuipers Munneke, R. S. W. van de Wal, and M. R. van den Broeke acknowledge support from the Polar Programme of the Netherlands Organization for Scientific Research (NWO/ALW)

Edited by: M. Sharp

\section{References}

Bales, R. C., McConnell, J. R., Mosley-Thompson, E., and Csatho, B.: Accumulation over the Greenland ice sheet from historcal and recent records, J. Geophys. Res., 106, 33813-33825, doi:10.1029/2001JD900153, 2001.

Bales, R. C., Guo, Q., Shen, D., McConnell, J. R., Du, G., Burkhart, J. F., Spikes, V. B., Hanna, E., and Cappelen, J.: Annual accumulation for Greenland updated using ice core data developed during 2000-2006 and analysis of daily coastal meteorological data, J. Geophys. Res., 114, D06116, doi:10.1029/2008JD011208, 2009.

Barker, H. W., Cole, J. N. S., Morcrette, J.-J., Pincus, R., Räisänen, P., von Salzenf, K., and Vaillancourtg, P. A.: The Monte Carlo Independent Column Approximation: An assessment using several global atmospheric models, Q. J. Roy. Meteor. Soc., 134, 1463-1478, doi:10.1002/qj.303, 2008.

Beljaars, A. C. M., Brown, A. R., and Wood, N.: A new parametrization of turbulent orographic form drag, Q. J. Roy. Meteor. Soc., 130, 1327-1347, doi:10.1256/qj.03.73, 2004.

Bougamont, M., Bamber, J. L., and Greuell, W.: A surface mass balance model for the Greenland Ice Sheet, J. Geophys. Res., 110, F04018, doi:10.1029/2005JF000348, 2005.

Box, J. E., Fettweis, X., Stroeve, J. C., Tedesco, M., Hall, D. K., and Steffen, K.: Greenland ice sheet albedo feedback: thermodynamics and atmospheric drivers, The Cryosphere, 6, 821-839, doi:10.5194/tc-6-821-2012, 2012.

Dee, D. P., Uppala, S. M., Simmons, A. J., Berrisford, P., Poli, P., Kobayashi, S., Andrae, U., Balmaseda, M. A., Balsamo, G., Bauer, P., Bechtold, P., Beljaars, A. C. M., van de Berg, L., Bidlot, J., Bormann, N., Delsol, C., Dragani, R., Fuentes, M., Geer, A. J., Haimberger, L., Healy, S. B., Hersbach, H., Hólm, E. V., Isaksen, L., Kållberg, P., Köhler, M., Matricardi, M., McNally, A. P., Monge-Sanz, B. M., Morcrette, J.-J., Park, B.-K., Peubey, C., de Rosnay, P., Tavolato, C., Thépaut, J.-N., and Vitart, F.: The ERA-Interim reanalysis: configuration and performance of the data assimilation system, Q. J. Roy. Meteor. Soc., 137, 553-597, doi:10.1002/qj.828, 2011.

ECMWF-IFS: Part IV : PHYSICAL PROCESSES (CY33R1), Technical Report, 2008.

Enderlin, E. M. and Howat, I. M.: Submarine melt rate estimates for floating termini of Greenland outlet glaciers (2000-2010), Journal of Glaciology, 59, 67-75, doi:10.3189/2013JoG12J049, 2013.

Ettema, J., van den Broeke, M. R., van Meijgaard, E., van de Berg, W. J., Box, J. E., and Steffen, K.: Climate of the Greenland ice sheet using a high-resolution climate model - Part 1: Evaluation, The Cryosphere, 4, 511-527, doi:10.5194/tc-4-511-2010, 2010.

Fettweis, X., Gallée, H., Lefebre, F., and van Ypersele, J.-P.: Greenland surface mass balance simulated by a regional climate model 
and comparison with satellite-derived data in 1990-1991, Clim. Dynam., 24, 623-640, doi:10.1007/s00382-005-0010-y, 2005.

Fettweis, X., Tedesco, M., van den Broeke, M., and Ettema, J.: Melting trends over the Greenland ice sheet (1958-2009) from spaceborne microwave data and regional climate models, The Cryosphere, 5, 359-375, doi:10.5194/tc-5-359-2011, 2011.

Fettweis, X., Hanna, E., Lang, C., Belleflamme, A., Erpicum, M., and Gallée, H.: Brief communication "Important role of the midtropospheric atmospheric circulation in the recent surface melt increase over the Greenland ice sheet", The Cryosphere, 7, 241248, doi:10.5194/tc-7-241-2013, 2013.

Fitzgerald, P. W., Bamber, J. L., Ridley, J. K., and Rougier, J. C.: Exploration of parametric uncertainty in a Surface Mass Balance Model applied to the Greenland Ice Sheet, J. Geophys. Res., 117, F01021, doi:10.1029/2011JF002067, 2012.

Greuell, W. and Oerlemans, J.: Sensitivity studies with a mass balance model including temperature profile calculations inside the glacier, Zeitschrift für Gletscherkunde und Glazialgeologie, 22, 101-124, 1986.

Hanna, E., Cappelen, J., Fettweis, X., Huybrechts, P., Luckman, A., and Ribergaard, M. H.: Hydrologic response of the Greenland ice sheet: the role of oceanographic warming, Hydrol. Process., 23, 7-30, doi:10.1002/hyp.7090, 2009.

Kuipers Munneke, P., van den Broeke, M. R., Lenaerts, J. T. M., Flanner, M. G., Gardner, A. S., and van de Berg, W. J.: A new albedo parameterization for use in climate models over the Antarctic ice sheet, J. Geophys. Res., 116, D05114, doi:10.1029/2010JD015113, 2011.

Lenaerts, J. T. M., van den Broeke, M. R., van Angelen, J. H., van Meijgaard, E., and Déry, S. J.: Drifting snow climate of the Greenland ice sheet: a study with a regional climate model, The Cryosphere, 6, 891-899, doi:10.5194/tc-6-891-2012, 2012.

Lin, Y.-L., Farley, R. D., and Orville, H. D.: Bulk Parameterization of the Snow Field in a Cloud Model, J. Appl. Meteorol., 22, 1065-1092, doi:10.1175/15200450(1983)022<1065:BPOTSF>2.0.CO;2, 1983.

Morcrette, J.-J., Barker, H. W., Cole, J. N. S., Iacono, M. J., and Pincus, R.: Impact of a new radiation package, McRad, in the ECMWF integrated forecast system, Mon. Weather Rev., 136, 4773-4798, doi:10.1175/2008MWR2363.1, 2008.

Nick, F. M., Vieli, A., Howat, I. M., and Joughin, I.: Large-scale changes in Greenland outlet glacier dynamics triggered at the terminus, Nat. Geosci., 2, 110-114, doi:10.1038/ngeo394, 2009.

Noël, B., Fettweis, X., van de Berg, W. J., van den Broeke, M. R., and Erpicum, M.: Sensitivity of Greenland Ice Sheet surface mass balance to perturbations in sea surface temperature and sea ice cover: a study with the regional climate model MAR, The Cryosphere, 8, 1871-1883, doi:10.5194/tc-8-1871-2014, 2014.

Rignot, E., Box, J. E., Burgess, E., and Hanna, E.: Mass balance of the Greenland ice sheet from 1958 to 2007, Geophys. Res. Lett., 35, L20502, doi:10.1029/2008GL035417, 2008.

Rignot, E., Velicogna, I., van den Broeke, M. R., Monaghan, A., and Lenaerts, J.: Acceleration of the contribution of the Greenland and Antarctic ice, Geophys. Res. Lett., 38, L05503/1-L05503/5, doi:10.1029/2011GL046583, 2011.

Siebesma, A. P., Soares, P. M. M., and Teixeira, J.: A Combined Eddy-Diffusivity Mass-Flux Approach for the Convective Boundary Layer, J. Atmos. Sci., 64, 1230-1248, doi:10.1175/JAS3888.1, 2007.
Smeets, C. and van den Broeke, M.: Temporal and Spatial Variations of the Aerodynamic Roughness Length in the Ablation Zone of the Greenland Ice Sheet, Bound.-Lay. Meteorol., 128, 315-338, doi:10.1007/s10546-008-9291-0, 2008.

Stark, J. D., Office, E. M., Donlon, C. J., Martin, M. J., and McCulloch, M. E.: OSTIA: An operational, high resolution, real time, global sea surface temperature analysis system, OCEANS 2007 - Europe, 1-4, doi:10.1109/OCEANSE.2007.4302251, Conference Publications, 2007.

Stroeve, J., Box, J. E., Gao, F., Liang, S. L., Nolin, A., and Schaaf, C.: Accuracy assessment of the MODIS 16-day albedo product for snow: comparisons with Greenland in situ measurements, Remote Sens. Environ., 94, 46-60, doi:10.1016/j.rse.2004.09.011, 2005.

Stroeve, J., Box, J. E., Wang, Z., Schaafc, C., and Barretta, A.: Re-evaluation of MODIS MCD43 Greenland albedo accuracy and trends, Remote Sens. Environ., 138, 199-214, doi:10.1016/j.rse.2013.07.023, 2013.

Stroeve, J. C.: Assessment of Greenland albedo variability from the advanced very high resolution radiometer Polar Pathfinder data set, J. Geophys. Res., 106, 360-374, doi:10.1016/S00344257(00)00179-6, 2001.

Sundqvist, H.: A parameterization scheme for non-convective condensation including prediction of cloud water content, Q. J. Roy. Meteor. Soc., 104, 677-690, doi:10.1002/qj.49710444110, 1978.

Tedesco, M., Serreze, M., and Fettweis, X.: Diagnosing the extreme surface melt event over southwestern Greenland in 2007, The Cryosphere, 2, 159-166, doi:10.5194/tc-2-159-2008, 2008.

Tedesco, M., Fettweis, X., van den Broeke, M. R., van de Wal, R. S. W., Smeets, C. J. P. P., van de Berg, W. J., Serreze, M. C., and Box, J. E.: The role of albedo and accumulation in the 2010 melting record in Greenland, Environ. Res. Lett., 6, 014005, doi:10.1088/1748-9326/6/1/014005, 2011.

Tompkins, A. M., Gierens, K., and Rädel, G.: Ice supersaturation in the ECMWF integrated forecast system, Q. J. Roy. Meteor. Soc., 133, 53-63, doi:10.1002/qj.14, 2007.

Undèn, P., Rontu, L., Järvinen, H., Lynch, P., Calvo, J., Cats, G., Cuxart, J., Eerola, K., Fortelius, C., Garcia-Moya, J. A., Jones, C., Lenderlink, G., Mcdonald, A., Mcgrath, R., Navascues, B., Nielsen, N. W., Degaard, V., Rodriguez, E., Rummukainen, M., Sattler, K., Sass, B. H., Savijarvi, H., Schreur, B. W., Sigg, R., and The, H.: HIRLAM-5, Scientific Documentation, Technical Report, 2002.

Uppala, S. M., Kållberg, P. W., Simmons, A. J., Andrae, U., Bechtold, V. D. C., Fiorino, M., Gibson, J. K., Haseler, J., Hernandez, A., Kelly, G. A., Li, X., Onogi, K., Saarinen, S., Sokka, N., Allan, R. P., Andersson, E., Arpe, K., Balmaseda, M. A., Beljaars, A. C. M., Berg, L. V. D., Bidlot, J., Bormann, N., Caires, S., Chevallier, F., Dethof, A., Dragosavac, M., Fisher, M., Fuentes, M., Hagemann, S., Hólm, E., Hoskins, B. J., Isaksen, L., Janssen, P. A. E. M., Jenne, R., Mcnally, A. P., Mahfouf, J.-F., Morcrette, J.-J., Rayner, N. A., Saunders, R. W., Simon, P., Ster, A., Trenberth, K. E., Untch, A., Vasiljevic, D., Viterbo, P., and Woollen, J.: The ERA-40 re-analysis, Q. J. Roy. Meteor. Soc., 131, 29613012, 2005.

van Angelen, J. H., Lenaerts, J. T. M., Lhermitte, S., Fettweis, X., Kuipers Munneke, P., van den Broeke, M. R., van Meijgaard, E., and Smeets, C. J. P. P.: Sensitivity of Greenland Ice Sheet surface mass balance to surface albedo parameterization: a study 
with a regional climate model, The Cryosphere, 6, 1175-1186, doi:10.5194/tc-6-1175-2012, 2012.

Van Angelen, J. H., van den Broeke, M. R., Wouters, B., and Lenaerts, J. T. M.: Contemporary (1969-2012) evolution of the climate and surface mass balance of the Greenland ice sheet, Surv. Geophys., doi:10.1007/s10712-013-9261-z, 2013.

Van de Berg, W., van den Broeke, M., Reijmer, C., and van Meijgaard, E.: Reassessment of the Antarctic surface mass balance using calibrated output of a regional atmospheric climate model, J. Geophys. Res., 111, D11104, doi:10.1029/2005JD006495, 2006.

Van de Wal, R., Greuell, W., van den Broeke, M. R., Reijmer, C. H., and Oerlemans, J.: Surface mass-balance observations and automatic weather station data along a transect near Kangerlussuaq, West Greenland, Ann. Glaciol., 42, 311-316, doi:10.3189/172756405781812529, 2005.

van de Wal, R. S. W., Boot, W., Smeets, C. J. P. P., Snellen, H., van den Broeke, M. R., and Oerlemans, J.: Twenty-one years of mass balance observations along the K-transect, West Greenland, Earth Syst. Sci. Data, 4, 31-35, doi:10.5194/essd-4-312012, 2012.

Van den Broeke, M. R., Smeets, P., Ettema, J., and Munneke, P. K.: Surface radiation balance in the ablation zone of the west Greenland ice sheet, J. Geophys. Res.-Atmos., 113, D13105, doi:10.1029/2007JD009283, 2008.

Van den Broeke, M. R., Smeets, P., and Ettema, J.: Surface layer climate and turbulent exchange in the ablation zone of the west Greenland ice sheet, Int. J. Climatol., 29, 2309-2323, doi:10.1002/joc.1815, 2009. van den Broeke, M. R., Smeets, C. J. P. P., and van de Wal, R. S. W. The seasonal cycle and interannual variability of surface energy balance and melt in the ablation zone of the west Greenland ice sheet, The Cryosphere, 5, 377-390, doi:10.5194/tc-5-377-2011, 2011.

Van Meijgaard, E., van Ulft, L. H., van de Berg, W. J., Bosveld, F. C., van den Hurk, B., Lenderink, G., and Siebesma, A. P.: Technical Report 302: The KNMI regional atmospheric climate model RACMO version 2.1, Royal Netherlands Meteorological Institute, De Bilt, 2008.

Van Meijgaard, E., van Ulft, L., Lenderink, G., de Roode, S., Wipfler, L., Boers, R., and Timmermans, R. M. A.: Refinement and application of a regional atmospheric model for climate scenario calculations of Western Europe, Climate Change Spatial Planning Publication, KvR 054/12, 2012.

van Wessem, J. M., Reijmer, C. H., M. Lenaerts, J. T., van de Berg, W. J., van den Broeke, M. R., and van Meijgaard, E.: Updated cloud physics in a regional atmospheric climate model improves the modelled surface energy balance of Antarctica, The Cryosphere, 8, 125-135, doi:10.5194/tc-8-125-2014, 2014.

White, P. W.: Part IV : PHYSICAL PROCESSES (CY23R4), Technical Report, 2001.

Wouters, B., Bamber, J. L., van den Broeke, M. R., Lenaerts, J. T. M., and Sasgen, I.: Limits in detecting acceleration of ice sheet mass loss due to climate variability, Nat. Geosci., 6, 613-616, doi:10.1038/ngeo1874, 2013. 